\title{
ANALYSIS OF POSTHARVEST LOSSES IN MANGO MARKETING IN MAKURDI LOCAL GOVERNMENT AREA OF BENUE STATE, NIGERIA
}

\section{${ }^{1}$ Onyia Chukwuemeka Chiebonam*, ${ }^{1}$ Chiemela Chinedum Jaachima and ${ }^{1}$ Joseph Deborah Chidimma}

${ }^{I}$ Department of Agricultural Economics, University of Nigeria, Nsukka, Enugu State, Nigeria. *Corresponding author: Tel: +2348032906932; Email: chinedum.chiemela@unn.edu.ng

\begin{abstract}
The study analyzed the postharvest losses in mango marketing in Makurdi Local Government Area of Benue State, Nigeria. Data for the study were collected from 120 respondents in four different markets (Modern, Wurukum, Railway and Northbank market), through the use of structured questionnaire. Descriptive statistics, multiple regression analysis and likert scale rating technique were used to analyze the data. The finding showed that the mean age of the marketers was 36.1 years, mean household size was 6.0, majority (43.3\%) of the marketers completed secondary school, majority (88.3\%) of the respondents were females, majority were married with a percentage of (63.3\%), also majority (56.7\%) of the marketers sold broken variety of mango. The result further indicated that the amount of basket of mango bought is significant at 5\% level of probability and positively affects the number of 7litre buckets of mango lost. Finally, the constraints with the highest mean values suggested the most essential constraints. The result showed that high degree of perishability (mean=3.8), lack of storage facility (mean=3.6), and inadequate grading and standardization (mean=2.9) were some of the major constraints. The study therefore recommends that efficient storage facilities should be made available to mango marketers in order to encourage large purchase of the produce and decrease postharvest losses government should rehabilitate the bad roads and create good road networks to solve the transportation problems of marketers, lastly, there should be provision of processing plant in strategic locations by the governments or non-governmental organization which will help to reduce postharvest losses.
\end{abstract}

Keywords: Mango, Post harvest loss, Markudi LGA

https://dx.doi.org/10.4314/jafs.v17i2.6

\section{INTRODUCTION}

Mango (Mangiferaindica) is among the most important fruits in Nigeria. It originates from south Asia and is cultivated in tropical and subtropical areas in over 90 countries (Akurugu, 2016). Nigeria's diverse climate makes it possible to produce virtually all agricultural products that can be grown in the tropical and semi-tropical areas of the world (Adegboye, 2004). The mango tree produces a fruit with great diversity with respect to form, size, colour and quality (Morton, Journal of the Faculty of Agriculture and Veterinary Medicine, Imo State University Owerri website: www ajol.info 
1987). The fruit can be put to a number of uses. For instance, ripe fruits can be made into juice, while unripe fruits can be processed into pickles and chutney (Samson, 1980). The mango fruit pulp which makes up 60-75\% of fresh fruit weight contains 15\% sugars, high amounts of vitamin A and some quantities of vitamins B and C (Samson, 1980). Although Nigeria occupies the 9th position among the ten leading mango producing countries of the world, Nigeria does not feature among the ten leading mango fruit exporters (FAOSTAT, 2007). Benue state on its own is one of the leading producers of mango in Nigeria (Avav\&Uza, 2002), the state is a major supplier of fresh mango fruits to consumers in other states of the Federation (Ajayi\&Nyishir, 2006). Sale of mango fruits and seedlings is a source of income to Benue farmers (Nyishir, 2004).

Mango is a highly perishable produce and survey has revealed that a substantial portion of the harvest is wasted annually due to improper harvesting and postharvest practices, diseases and lack of facilities and technology to extend storage life (Kader, 1992). Farmers in Nigeria produce a lot to boost the economy, but most of these produce are lost at the postharvest stage (Olayemi, Adegbola, Bamishaya \& Awagu, 2012). Postharvest losses as the term implies are losses which occur to a farmer's produce after harvest. They are losses which occur between the time of harvest, marketing and the time of human consumption, thus can be divided into quantitative and qualitative losses (Kader \& Rolle, 2004). In developing countries, both quantitative and qualitative losses of agricultural product occur at all stages in the post-harvest chain, from harvesting, through handling, storage, processing, packaging, transportation and marketing until crops are delivered to the final consumers (Kader, 2003).

Post-harvest losses are not only of perishable crops but also grains, livestock and fish. It's estimated that as much as $25 \%$ of fruits, are wasted after harvest. According to Kader (2002), approximately one third of all fresh fruits and vegetables are lost before they reach the consumers. Another estimate suggests that about 30-40\% of total fruits and vegetables production is lost in between harvest and final consumption (Salami, Ahmadi, Keyhani \& Sarsaifee, 2010). Odeyemi \& Daramola (2000) reported that an essential objective in food storage is to preserve the quality of the food commodities so as to prevent food wastage and make food available all the time. It is not enough to produce the amount of food required to meet the consumption need of Nigeria's populace, emphasis should be on preventing losses at each stage of the produce's lifespan. One critical stage where major losses occur is in the marketing of the product. Idachaba, (1987) noted that bumper harvest of 1985 and 1986 have conferred new outlook to the view point that Nigeria's central problem is not production parse but marketing and distribution.

Survey carried out on postharvest food losses in some communities in Nigeria revealed that a high percentage of fruits and vegetables are lost with a substantial amount recorded during storage and marketing (Mijinyawa, 2002). Oganga (1996) opined that the goal of universal food security would not be attained if problems associated with postharvest losses are not prevented. Also, Okezie (1998) further explained that the perception of postharvest losses is a challenge for 
producers, marketers and the government. In order to increase food availability, it is not enough to increase the productivity in agriculture but there is also a great need to lower the losses.

Farmers and food sellers have been concerned about losses since agriculture began. Yet the problem of how much food is lost after harvest to processing, spoilage, insects and rodents, or to other factors takes on greater importance as world food demand grows. In developing countries like Nigeria, over $85 \%$ of food consumed is obtained from the farm and the inability of food to be available at all season is affected by postharvest losses, this unavailability of food at all season causes food insecurity (Ahmed, Idris-Adeniyi, \&Lawal,2015). Postharvest loss has been a limiting factor to food availability in Nigeria, even though increased yield has been found to be possible, postharvest losses have prevented the effect of the increase to be felt on the income of the marketers (Arowojolu, 2000). Not only are losses clearly a waste of food product but they also represent a similar waste of human effort, farm input, livelihood, investment and scarce resources such as water (World Resource Institute, 1998). Food loss and waste have many negative economic and environmental impacts. Economically, they represent a wasted investment that can reduce farmers' income and increase consumers' expenses. Environmentally, food loss and waste inflicts a host of impacts, including unnecessary greenhouse gas emissions and inefficient water and land use, which in turn can lead to degradation of the natural ecosystem and its services (Lipinski et al. 2013).

These losses are exceptionally high in succulent perishable fruit like the mango fruit (Parfitt, Barthel, \& Macnaughton, 2010). The marketing system for horticultural product such as mango is more complex as it is a perishable product and dependent on climate conditions (Van der Vorst \&Beulens, 2002; Salin, 1998). In Nigeria, postharvest losses in mango fruit is enormous, the marketing system of this fruit places about $75 \%$ of the burden of these losses on the fruit marketers, this is because the marketing chain of this fruit involves buying in small quantities from scattered farm holdings and assembling the fruits in bulk for transportation to the urban centers (Ahmed et al., 2015).

Mango is a highly perishable produce and surveys has revealed that a substantial portion of the harvest is wasted annually due to improper harvesting and postharvest practices, diseases and lack of facilities and technology to extend storage life (kader, 1992). The amount of losses within a supply chain is dependent on activities such as handling, storage, processing, packaging, transportation and marketing (Kader, 2003).

Oganga (1996) has stated that the goal of universal food security would not be attained if problems associated with postharvest losses are not prevented. Since the marketing margin of this fruit determines the price and hence the income that will accrue to the marketers, it is pertinent to investigate the postharvest losses in mango marketing (Ahmed, et al., 2015). Research has historically focused on how to increase the production of the mango fruit; however, little emphasis has been placed on the postharvest losses incurred in mango marketing. In addition to this, there is still inadequate information existing on the postharvest losses in mango 
marketing in the study area. Due to this knowledge gap, this study therefore analyzes the postharvest losses in mango marketing in Makurdi Local Government Area of Benue State; describe the socio-economic characteristics of mango marketers in the study area; ascertain the determinants of postharvest losses; and identify constraints to mango marketing in the study area

\section{STUDY AREA, MATERIALS AND METHODS}

\section{Study Area and Sampling}

The study area was Makurdi Local Government Area, Benue state, Nigeria. The city has a population of 300,000 persons (National Population Commission, 2007), and lies between latitudes $7^{\circ} 44^{\prime}$ North of the equator and Longitude $8^{\circ} 31^{\prime}$ east of the Greenwich meridian. It is a $16 \mathrm{~km}$ radius circle, covering $804 \mathrm{~km}^{2}$ land mass. Makurdi Local Government Area comprises eleven (11) council wards, namely Mbalagh, Agan, NorthBank I and NorthBank II. Others are Fiidi, Wailomayo, Baa, Modern Market, Ankpa/Wadata, Clerk Market and Central/South Mission. Being situated in the Lower Benue Valley, the relief of the Local Government Area (L.G.A) is generally low, with heights ranging between 73 meters and 167 meters above sea level. The soils of Makurdi generally are highly ferruginous tropical soils (Areola, 1983; Nyagba, 1995). Multi-stage sampling techniques were used to select 120 respondents for the study.

\section{Empirical analysis and model specification}

Data for the study was collected from primary source. Primary data were generated by using a set of structured, pre-tested and validated questionnaire. Descriptive statistics and multiple regressions were used in realizing the objectives.

\section{Likert Scale Rating Technique}

A Likert scale is a psychometric scale commonly used in questionnaires, and is the most widely used scale in survey research. When responding to a Likert questionnaire item, respondents specify their level of agreement or disagreement on a symmetric agree -disagree scale for a series of item statements. Thus, the scale captures the intensity of their feelings. The perceived impediments to be weighted include seasonality of products, inadequate grading and standardization, high degree of perishability, lack of storage facilities, no uniform price, inadequate market information, poor transportation network, high cost of transportation and high level of competition. A 4-point rating scale was used in this work to determine the constraints in mango marketing with corresponding values of $4,3,2$, and 1 respectively. The mean score of respondents based on the 4-point rating scale was computed as;

$$
4+3+2+1 / 4=10 / 4=2.50 \text { cut off point }
$$




\section{DATA DESCRIPTION, RESULTS AND DISCUSSION}

\section{Data description}

The result of descriptive statistics of the socioeconomic variables used in the analysis is presented in Table 1 below. Some of the variables measured household characteristics expected to influence postharvest losses. These include household size, level of education of the respondents, age, gender of the household head and occupation.

\section{Determinants of Postharvest Losses}

The result for ascertaining the determinants of postharvest losses in mango marketing is shown in Table 2.

Multiple regression analysis was used to ascertain the determinants of postharvest losses among mango marketers in the study area. The independent variables were: gender, age, marital status, mango variety, transportation method, member of marketing union, number of basket bought, accessible road, price regulation, source of market information, free entrance and length of sale. The dependent variable was total bucket of mango lost per month.

The result showed $\mathrm{R}^{2}$ value of 0.382 implies that $38.2 \%$ of the variations in postharvest losses were accounted for by the independent variables. From the table above, the result further showed that total number of basket bought positively, significantly and statistically affected the total number of buckets at 5\% significant level. This implies that an increase in the number of basket bought will lead to a positive increase in the total number of bucket lost among mango marketers in the study area. This result is in line with the work done by Ndirangu, et al (2017) that marketers purchasing large volumes experience more losses than those purchasing fewer quantities. Those with high quantities have challenges of handling and storage. However, unlike the research conducted by Ndirangu, et al (2017) in Kenya, gender and age were not significant determinants of postharvest losses in the study area.

\section{Constraints Associated with Mango Marketing}

The problems associated with mango marketing (seasonality of products, inadequate grading and standardization, high degree of perishability, lack of storage facility, no uniform price, overregulation of business, inadequate market information, high cost of transportation, lack of processing plant, presence of market union interference, high level of competition and political instability) were analyzed using a 4-point rating scale.

The mean score of respondents based on the 4-point rating scale will be computed as; $(4+3+2+1) / 4=10 / 4=2.50$ cut off point. Any constraint whose mean fall below 2.5 is considered as not serious while those constraints with means above 2.5 is considered serious.

Table 3 showed the means and decisions for constraints associated with the marketing of mango. The constraints with the highest mean values suggest the most essential constraints in the marketing of mango in Markurdi Local Government Area of Benue State. From the table, it can Journal of the Faculty of Agriculture and Veterinary Medicine, Imo State University Owerri website: www ajol.info 
be seen that, seasonality of products (2.6), inadequate grading and standardization (2.9), high degree of perishability (3.8), lack of storage facility (3.6), no uniform price (2.8), inadequate market information (2.7), high cost of transportation (2.8), lack of processing plant (2.7), high level of competition (2.8) were major constraints influencing the marketing of marketing in the study area which is consistent with the research carried out by Durodola, Wahab, M \& Ibikunle (2017).

\section{CONCLUSION AND RECOMMENDATION}

It is recommended that efficient storage facilities be made available by government to mango marketers to encourage large purchase of the produce and decrease postharvest losses. Also the government should also provide packing houses at production and market centers to maintain quality along delivery channels to reduce postharvest losses. 


\section{REFERENCES}

Adegeye, A.J., \& Dittoh, J. S. (Eds.) (1985). Essentials for agricultural economics. Ibadan, Nigeria: Impact Publishers Nig. Ltd. 113-119

Ahmed, B.O, Idris-Adeniyi, K.M. \& Lawal A.O. (2015). Food Security and Post-Harvest Losses in Fruit Marketing in Lagos Metropolis, Nigeria. Discourse Journal of Agriculture and Food Sciences 3(3), 52-58

Akurugu G.K. (2016). Evaluation of post-harvest handling and marketing of mango (Mangiferaindica. L) In Ghana (A case study in Northern region). Journal of Research in Agriculture and Animal Science 4 (5), 04-09

Ajayi, A. R. \& Nyishir, S. A. (2006). Mango variety production, marketing and consumption preferences among households in Benue State, Nigeria. www.patnsukjournal.net/currentissue

Areola, O.O. (1983). Soil and Vegetal Resources in Nigeria. In Oguntoyinbo, J. S., Areola, O.O. \& Filani, M. (Eds.) A Geography of Nigerian Development. Ibadan: Heinemann Educational Books Ltd.

Arowojulo O (2000). Analysis of Rural Women's use of Cassava Post Harvest Technologies in Oyo state. M.Sc Project.Department of Agricultural Economics and Rural Development, University of Ibadan, Nigeria.

Avav T. \& Uza D. V. (2002). Agriculture In: Pigeonniere, A. LAfrica Atlases: Nigeria, Les Editions J. A., Paris, 92-95.

FAOSTAT (2007). FAO Statistics, Food and Agriculture Organization of the United Nations, Rome, Italy.http://faostat.fao.org/.

Folayan, J. A. (2013). Determinants of Post Harvest Losses of Maize in Akure North Local Government Area of Ondo State, Nigeria. Journal of Sustainable (2)1, 12-19

Idachaba, F.S. (1987). Rural Infrastructures in Nigeria. Ibadan University Press: Ibadan.

Kader, A. A. (1983). Postharvest quality maintenance of fruits and vegetables in developing counties. In M. Libermanpost harvest physiology and cost presentation plenum publication com New York.

Kader, A. A. (2002). Postharvest biology and technology: An overview. In Kader, A.A. Postharvest technology of horticultural crops (Ed.). University of California, Division of Agriculture and Natural Resource.Special Publ. 331.

Kader, A. A. (2003). A perspective on postharvest horticulture (1978-2003). 
Kader, A.A. (1992). Postharvest Biology and Technology; An Overview. In Kader, A.A. Postharvest Technology of Horticultural Crops (Ed.). University of California. Publication No. 3311, 279-285.

Kader, A.A. (2003). A Perspective on post-harvest horticulture (1978-2003). Journal of Horticultural Science, 38, 1004-1008.

Kader, A.A., \&Rolle, R.S. (2004). The Role of Postharvest Management in Assuring the Quality and Safety of Horticultural Produce.FAO: Rome.

Lipinski,B., Craig, H., James, L., Kitinoja,L., Waite, R., \& Tim, S.(2013). Reducing food loss and waste. World Resource Institute.

Lydia, P. I (2013). Economic Study of tomato marketing in South East Nigeria. An unpublished undergraduate project submitted to the Department of Agricultural Economics, University of Nigeria, Nsukka.

Mijinyawa, Y. (2002). Post-Harvest Losses: A Dilemma in Ensuring Food Security in Nigeria.

Morton, J. (1987). Mango. In: Morton, J. F. Fruits of the Warm Climate. Miami, Florida, 221239

Nyagba, J. L. (1995) Soils and Agriculture in Benue State. In Denga, D.I. Benue State: The Land of Great Potentials: A Compendium (Ed.). Calabar: Rapid Educational Publishers.

Nyishir, S. A. (2004). Mango Variety Production, Marketing and Consumption Among Households in Benue State. Postgraduate Thesis, Department of Agricultural Extension, University of Nigeria, Nsukka.

Odeyemi O. O \& Daramola A.M. (2000). Storage practices in the tropics. Food Storage and Pest Problem. 1(253).

Oganga M. (1996). Postharvest Food Losses, A Key Demission of Increasing African's Food Supply. Paper presented at the first African wide exhibition and workshop on African food processing technologies for commercialization. June Kinya - sponsored by Ran forum and UNDP.

Okezie, B.O. (1998). World food security: the role of postharvest technology. Retrieved from http://agris.fao.org/agris-search/search.do?recordID=US1997054681

Parfitt, J., Barthel, M. \&Macnaughton, S. (2010). Food Waste within Food Supply Chains: Quantification and Potential for Change to 2050. PhilosophicalTransaction of the Royal Society, 365, 3065-3081.

Salami, P., Ahmadi, H., Keyhani, A., \&Sarsaifee, M. (2010). Strawberry post-harvest energy losses in Iran.

Samson, J. A. (1980). Tropical Fruits. London: Longman Group Limited.

Journal of the Faculty of Agriculture and Veterinary Medicine, Imo State University Owerri website: www ajol.info 
Shum, M. (2012). Market structure (perfect structure and monopoly). Retrieved from www.hss.caltech.edu/mshum/.... matt2.

Van der Vorst, J.G.A.J. \&Beulens, A.J.M. (2002). Identifying Sources of Uncertainty to Generate Supply Chain Redesign Strategies.International Journal of Physical Distribution \& Logistics Management, 32(6), 409-30.

Van Melle, C. \& S. Buschmann (2013): Comparative analysis of Mango Value Chain models in Benin, Burkina Faso and Ghana, In: Rebuilding West Africa's Food Potential, A. Elbehri (ed.), FAO/ IFAD. 


\section{APPENDIXES}

Table 1: Assignment and descriptive statistics of variables

\begin{tabular}{|c|c|c|c|c|c|}
\hline Variables & $\mathbf{N}$ & $\begin{array}{l}\text { Minimu } \\
\text { m }\end{array}$ & $\begin{array}{l}\text { Maximu } \\
\text { m }\end{array}$ & Mean & $\begin{array}{c}\text { Std. } \\
\text { Deviation }\end{array}$ \\
\hline Gender & 120 & 1.00 & 2.00 & 1.8833 & .32373 \\
\hline Age of marketer & 120 & 17.00 & 85.00 & 36.1000 & 12.06578 \\
\hline Marital status & 120 & 1.00 & 3.00 & 1.8667 & .59565 \\
\hline $\begin{array}{l}\text { Level of } \\
\text { education }\end{array}$ & 120 & 1.00 & 6.00 & 4.2333 & 1.33234 \\
\hline Household size & 120 & 1.00 & 16.00 & 6.0667 & 2.90451 \\
\hline $\begin{array}{l}\text { Member market } \\
\text { union }\end{array}$ & 120 & .00 & 1.00 & .4500 & .50169 \\
\hline $\begin{array}{l}\text { No of basket } \\
\text { purchased }\end{array}$ & 120 & .50 & 50.00 & 7.2083 & 7.74613 \\
\hline Accessible road & 120 & .00 & 1.00 & .6167 & .49030 \\
\hline Price regulated & 120 & .00 & 2.00 & .3500 & .57711 \\
\hline $\begin{array}{l}\text { Source of } \\
\text { market } \\
\text { information }\end{array}$ & 120 & 1.00 & 5.00 & 2.9833 & 1.22808 \\
\hline Free entrance & 120 & .00 & 1.00 & .3333 & .47538 \\
\hline
\end{tabular}

Journal of the Faculty of Agriculture and Veterinary Medicine, Imo State University Owerri website: www ajol.info 
Table 2: Result of regression ascertaining the determinants of postharvest losses

\begin{tabular}{lllll}
\hline Parameter & Std. Error & Coefficients & t & Sig. \\
\hline (Constant) & 4.118 & 4.918 & 1.194 & .238 \\
Gender & 2.262 & .093 & .720 & .475 \\
Age of marketer & .077 & .026 & .160 & .874 \\
Marital status & 1.789 & -.131 & -.951 & .347 \\
Mango variety & 1.464 & -.020 & -.154 & .878 \\
Transport method & 1.801 & .081 & .506 & .616 \\
Member of market union & 1.896 & -.104 & -.622 & .537 \\
Number of basket bought & .119 & .429 & 2.631 & $.011^{* *}$ \\
Accessible road & 2.084 & -.189 & -1.051 & .299 \\
Price regulation & 1.725 & .171 & 1.285 & .205 \\
Source of information & 1.467 & -.055 & -.426 & .672 \\
Free entrance & 1.754 & -.011 & -.072 & .943 \\
Length of sale & .672 & .109 & .720 & .475 \\
a. Dependent Variable: bucket lost & per month & & &
\end{tabular}

** significant at $5 \%$ level.

\section{Model Summary}

$\begin{array}{ccccc}\text { Model } & \mathrm{R} & \mathrm{R} \text { Square } & \text { Adjusted R Square } & \begin{array}{c}\text { Std. Error of the } \\ \text { Estimate }\end{array} \\ 1 & .618^{\mathrm{a}} & .382 & .224 & 4.997\end{array}$

a. Predictors: (Constant), length of sale, source of information, marital status, price regulation, gender, mango variety, free entrance, age of marketer, transportation method, member of market union, number of basket bought, accessible road

Source: Field survey, 2018

Journal of the Faculty of Agriculture and Veterinary Medicine, Imo State University Owerri website: $w$ ww ajol.info 
Table 3 Constraints of mango marketing $(\mathrm{N}=120)$

\begin{tabular}{lll}
\hline Constraints & Mean & Decision Rank \\
\hline Seasonality of product & 2.6 & Serious $6^{\text {th }}$ \\
Inadequate grading and standardization & 2.9 & Serious $^{\text {rd }}$ \\
High degree of perishability & 3.8 & Serious $^{\text {st }}$ \\
Lack of storage & 3.6 & Serious $2^{\text {nd }}$ \\
No uniform price & 2.9 & Serious $3^{\text {rd }}$ \\
Over-regulation of business & 2.3 & Not serious NC \\
Inadequate marketing of information & 2.7 & Serious $5^{\text {th }}$ \\
High cost of transportation & 2.8 & Serious $4^{\text {th }}$ \\
Lack of processing plant & 2.7 & Serious $5^{\text {th }}$ \\
Presence of market union interference & 2.0 & Not serious NC \\
High level of competition & 2.8 & Serious $4^{\text {th }}$ \\
Political instability & 2.3 & Not serious NC \\
\hline
\end{tabular}

$* \mathbf{N C}=$ Non Constraint.

Source: Field survey, 2018

Journal of the Faculty of Agriculture and Veterinary Medicine, Imo State University Owerri website: $w$ ww ajol.info 